\title{
Plasmid Involvement in Production of and Immunity to the Staphylococcin-like Peptide Pep 5
}

\author{
By HILDEGARD ERSFELD-DRESSEN, HANS-GEORG SAHL* AND \\ HENNING BRANDIS \\ Institut für Medizinische Mikrobiologie und Immunologie der Universität Bonn, Venusberg, \\ D-5300 Bonn I, Federal Republic of Germany
}

(Received I2 April 1984 ; revised 12 June 1984)

\begin{abstract}
The staphylococcin-like peptide Pep 5 is produced by the penicillin resistant strain Staphylococcus epidermidis 5. This strain is immune to the peptide. Plasmid analysis of $S$. epidermidis 5 by agarose gel electrophoresis and electron microscopy demonstrated five plasmids with molecular weights ranging from $5.8 \times 10^{6}$ to $29 \times 10^{6}$. Variants of $S$. epidermidis 5 not producing Pep 5 or which had become penicillin sensitive were induced by various curing treatments. Strains lacking the $13.9 \times 10^{6}$ mol. wt plasmid (pED502) had lost penicillin resistance, and those lacking the $12.3 \times 10^{6} \mathrm{~mol}$. wt plasmid (pED503) failed to produce Pep 5. pED503 is also responsible for the immunity of the producer cell to Pep 5. Plasmid pED502 could be transformed into $S$. aureus $R N 981$ which then became resistant to penicillin. pED503 could not be transformed into $S$. aureus RN 981, but could be transformed into $S$. epidermidis 5 variants previously cured of this plasmid; the transformants then regained the properties of Pep 5 production and immunity.
\end{abstract}

\section{INTRODUCTION}

Although there are numerous reports on bacteriocins of Gram-positive organisms (Tagg et al., 1976), little is known about the genetic elements controlling their production. Bernhard et al. (1978) demonstrated that a plasmid of molecular weight $45 \times 10^{6}$ was responsible for bacteriocin production in Bacillus cereus, and Rostas et al. (1980) identified a $30.9 \times 10^{6} \mathrm{~mol}$. wt plasmid encoding for megacin A. Plasmids involved in the production of Staphylococcus aureus staphylococcins have been reported by Gagliano \& Hinsdill (1970), Jetten \& Vogels (1973), Dajani \& Taube (1974), Rogolsky et al. (1974) and Warren et al. (1974). However, nothing is known about the genetic control of staphylococcin production in $S$. epidermidis, although staphylococcin 1580, isolated and characterized by Jetten \& Vogels (1972) and Jetten et al. (1972), is the most thoroughly studied bacteriocin produced by a staphylococcal strain.

Pep 5, a staphylococcin-like substance produced by $S$. epidermidis 5 , is different from the above-mentioned staphylococcins because of its narrow activity spectrum (only staphylococci and micrococci are sensitive) and its low molecular weight of 6000 (Sahl \& Brandis, 1981). Furthermore, it is a strongly basic peptide causing a rapid efflux of low molecular weight compounds from the cytoplasm of sensitive bacteria (Sahl \& Brandis, 1982, 1983). Recently, Nakamura et al. (1983) isolated a $S$. aureus bacteriocin which is similar to Pep 5 in its molecular weight $(5000)$ and its isoelectric point $(10.0)$; however, in contrast to Pep 5 it is active against many Gram-positive bacteria. The genetic determinants of this staphylococcin have not yet been elucidated.

In the present report, we demonstrate by curing studies and transformation results that a 12.3 $\times 10^{\circ} \mathrm{mol}$. wt plasmid is involved in the production of Pep 5 and in the immunity of the producer strain to this substance. 
Table 1. Bacterial strains

\section{Bacterial strains}

Staphylococcus cohnii 22

S. epidermidis 5

S. epidermidis S Pep 5-

$S$. epidermidis 5 Pen -

$S$. aureus RN $450=8325-4$

$S$. aureus RN 981
Properties

Clinical isolate, indicator for Pep 5 production.

Clinical isolate, wild-type, Pep 5 producer (Pep 5*). penicillin resistant (Pen ${ }^{+}$).

Derivative of $S$. epidermidis 5; Pep 5 , Pen ${ }^{*}$

Derivative of $S$. epidermidis 5; Pep $5^{\circ}$, Pen $^{-}$

Nonlysogenic derivative of $S$. aureus NCTC 8325.

Derivative of strain 8325-4, recAl.
Source or reference

Sahl \& Brandis (1981)

Sahl \& Brandis (1981)

This paper

This paper

Novick (1967)

Wyman et al. (1974)

\section{METHODS}

Bacterial strains and culture conditions. Bacterial strains used are listed in Table 1. Strains were maintained on Tryptone soya agar (TSA) or subcultured weekly on blood agar plates. The basic medium for growth of staphylococcal strains in liquid culture was Tryptone soya broth (TSB). TSB/YE/Gly contained additionally $0.3 \%$ yeast extract and 0.5\% glycine. Pep 5 was isolated and purified as described previously (Sahl \& Brandis, 1981).

Plasmid pattern of S. epidermidis S. Plasmid DNA was initially prepared as a cleared lysate and subsequently banded on $\mathrm{CsCl}$ /ethidium bromide gradients (Clewell \& Helinski, 1969; Novick \& Bouanchaud, 1971). Plasmid DNA was recovered and plasmid masses were determined by electron microscopy (Kleinschmidt, 1968) using phages $\lambda d v 1$ and PM2 as internal size standards.

Plasmid screening. For the rapid isolation of plasmid DNA the alkaline extraction procedure of Birnboim \& Doly (1979) was slightly modified. The staphylococcal strains were grown at $35^{\circ} \mathrm{C}$ with shaking in $50 \mathrm{ml}$ TSB/YE/Gly to an $O D_{000}$ of 0.8 to 1.0 . Cells were centrifuged $\left(9000 \mathrm{~g}, 4^{\circ} \mathrm{C}, 10 \mathrm{~min}\right)$, and resuspended in $\mathrm{I} \mathrm{ml}$ of a solution containing $50 \mathrm{~mm}$-glucose, $10 \mathrm{~mm}$-EDTA, $25 \mathrm{~mm}$-Tris/ $/ \mathrm{HCl}$ (pH 8), and lysostaphin (Sigma) - $75 \mu \mathrm{g} \mathrm{ml}-1$ for $S$. epidermidis, and $40 \mu \mathrm{g} \mathrm{ml}{ }^{-1}$ for $S$. aureus. Further isolation steps were essentially as described by Birnboim \& Doly (1979), except that ten times larger volumes were used. Volumes of 20 to $40 \mu$ l of the final DNA preparation were subjected to electrophoresis under standard conditions $(0.8 \%$ horizontal gels, $50 \mathrm{~V}$ for $16 \mathrm{~h}$ at ambient temperature).

Curing. For plasmid elimination the following conditions were employed: (i) growth in liquid culture (TSB) containing acriflavine $\left(25 \mu \mathrm{g} \mathrm{ml}^{-1}\right)$, SDS $(30 \mu \mathrm{g} \mathrm{ml}-1)$ (Sonstein \& Baldwin, 1972), and either ethidium bromide $\left(2.4\right.$ or $3.6 \mu \mathrm{g} \mathrm{ml}^{-1}$ ) (Bouanchaud et al., 1968; Warren et al., 1974) or acridine orange $\left(15 \mu \mathrm{g} \mathrm{ml} \mathrm{l}^{-1}\right.$ ) at 35 or $42{ }^{\circ} \mathrm{C}$; (ii) passage of the organisms at $39^{\circ} \mathrm{C}$ over $6 \mathrm{~d}$ in liquid culture (Laufs \& Kaulfers, 1977). Control cultures were incubated at $35^{\circ} \mathrm{C}$ for various periods of time. After $24 \mathrm{~h}$ and $48 \mathrm{~h}$ the cultures were diluted and plated on TSA to obtain a suitable number of colonies for replica plating. Treated cultures were examined for loss of bacteriocin activity and penicillin resistance. Colonies that failed to produce inhibition zones after $24 \mathrm{~h}$ of incubation at $37^{\circ} \mathrm{C}$ were scored as Pep $5^{-}$and those not growing after replica plating on TSA + penicillin ( $3 \mu \mathrm{g} \mathrm{ml}{ }^{-1}$ ) as Pen ${ }^{-}$. Pep 5 production was assayed as described by Sahl \& Brandis (1981) with $S$. cohnii 22 as indicator strain. Putative cured colonies were picked from the master plates and characterized biochemically and by their plasmid profiles.

Transformation. Methods and media for preparation of protoplasts were essentially as described for $B$. subtilis by Chang \& Cohen (1979), modified for staphylococci by Lindberg (1981) and Götz et al. (1981). Transformation of protoplasts was only performed with purified plasmid DNA. Protoplasts of $S$. aureus and S. epidermidis were prepared with lysostaphin at $30 \mu \mathrm{g} \mathrm{m} \mathrm{m}^{-1}$ and $60 \mu \mathrm{g} \mathrm{m} \mathrm{m}^{-1}$, respectively. Formation of protoplasts was observed by phase contrast microscopy. Controls included (i) plating the recipient culture without addition of plasmid DNA. and (ii) treatment of DNA with pancreatic deoxyribonuclease $\mathrm{l}(40 \mu \mathrm{g}$ in $10 \mu \mathrm{l}$ hypertonic buffer) for $\mathrm{I} \mathrm{h}$ before the addition of protoplasts.

For phenotypic expression the protoplasts were incubated in $\mathrm{HBM}$ at $30^{\circ} \mathrm{C}$ and $37^{\circ} \mathrm{C}$ for $4 \mathrm{~h}$ and then plated on DM3 regeneration medium.

When transformants were selected for penicillin resistance, they were plated on DM3 plates containing penicillin $\left(3 \mu \mathrm{g} \mathrm{m} \mathbf{m}^{-1}\right)$ and incubated at $37^{\circ} \mathrm{C}$ for $3 \mathrm{~d}$. For detection of Pep $5^{+}$transformants, samples of appropriate dilutions were plated on DM 3 and incubated at $37^{\circ} \mathrm{C}$ for $2 \mathrm{~d}$. Pep 5 producing strains were jdentified after replica plating by means of the deferred antagonism test, using $S$. cohnii 22 as indicator (Sahl \& Brandis, 1981).

\section{RESULTS AND DISCUSSION}

\section{Plasmid elimination from $S$. epidermidis 5}

The electron microscopic examination of plasmid DNA isolated from wild-type $S$. epidermidis 5 revealed five plasmids. The molecular weights were determined as $5.8 \times 10^{6}$, 
Table 2. Size estimates of plasmids in S. epidermidis 5

\begin{tabular}{lcc} 
& $10^{-6} \times$ Molecular weight \pm SD \\
\cline { 2 - 3 } Plasmid & Agarose gel analysis* & Electron microscopyt \\
pED501 & $28.5 \pm 0.8$ & $29.0 \pm 0.5(96)$ \\
pED502 & $14.2 \pm 0.6$ & $13.9 \pm 0.2(88)$ \\
pED503 & $12.7 \pm 0.6$ & $12.3 \pm 0.2(132)$ \\
pED504 & $8.9 \pm 0.4$ & $8.8 \pm 0.3(92)$ \\
pED505 & $5.4 \pm 0.2$ & $5.8 \pm 0.2(64)$
\end{tabular}

- Based on the results of 13 independent analyses using the plasmids of Escherichia coli V517 (Macrina et al., 1978) as reference markers.

+ Size estimates made from open circular contour lengths using the phages $\lambda d v 1$ and PM2 as an internal reference (four independent preparations). The numbers in parentheses are the numbers of molecules measured.

$8.8 \times 10^{6}, 12.3 \times 10^{6}, 13.9 \times 10^{6}$ and $29 \times 10^{6}$, based on their contour lengths, using phage $\lambda \mathrm{dvl}$ and phage PM2 as internal standards (Table 2).

The plasmid pattern of wild-type $S$. epidermidis 5 in agarose gels is shown in Fig. I (a). Five plasmid bands, in addition to a faint chromosomal band, could be detected, with molecular weights ranging from $5.4 \times 10^{6}$ to $28.5 \times 10^{6}$ (Table 2). Spontaneous loss of the ability to produce Pep 5 could not be detected by repeated subculturing of $S$. epidermidis 5 . Curing experiments using acriflavine and SDS were unsuccessful in isolating Pep 5 negative or penicillin sensitive variants of strain 5 .

A 6 d passage at $39^{\circ} \mathrm{C}$, however, produced Pep 5 negative ( $S$. epidermidis 5 Pep $5^{-}$) as well as penicillin sensitive variants ( $S$. epidermidis $5 \mathrm{Pen}^{-}$) with percentage ranges of $2.8 \%$ and $3.4 \%$, respectively. Curing with ethidium bromide at $35^{\circ} \mathrm{C}$ and $42{ }^{\circ} \mathrm{C}$ for $24 \mathrm{~h}$ and $48 \mathrm{~h}$ resulted only in Pep 5 negative variants at a frequency of $2.1 \%$ to $4.4 \%$. In contrast, acridine orange $\left(15 \mu \mathrm{g} \mathrm{ml}{ }^{-1}, 42{ }^{\circ} \mathrm{C}, 48 \mathrm{~h}\right)$ eliminated penicillin resistance with a curing rate of $3.4 \%$. Jetten \& Vogels (1973), Dajani \& Taube (1974) and Rogolsky et al. (1974) have also described an extrachromosomal mechanism of bacteriocin production in $S$. aureus by using different curing agents. None of our curing treatments yielded such high curing rates as were obtained for the $S$. aureus staphylococcins. Acridine orange, acriflavine and SDS were not effective in curing Pep 5 production, whereas SDS was an excellent curing agent (100\%) in $S$. aureus 89 (Jetten \& Vogels, 1973).

After repeated subculturing, no reversion to the parent phenotype of Pep 5 production and penicillin resistance could be demonstrated in cured strains. To rule out the possibility that these 'cured' variants might be contaminants, they were subjected to a number of taxonomic and biochemical tests. In all tests, $S$. epidermidis 5 wild-type and its Pep 5 negative and penicillin sensitive variants reacted identically.

To confirm that the production of Pep 5 and penicillin resistance were plasmid determined, the plasmid compositions of the cured variants were analysed by agarose gel electrophoresis as well as by electron microscopy. In both cases it could be demonstrated that all Pep $5^{-}$strains of $S$. epidermidis 5 had lost the $12.3 \times 10^{6}$ mol. wt plasmid (pED503) and all Pen- strains of $S$. epidermidis 5 the $13.9 \times 10^{6} \mathrm{~mol}$. wt plasmid (pED502). Between 10 and 15 strains of each cured variant were tested. Electrophoresis patterns of wild-type $S$. epidermidis 5 and samples of its cured variants are shown in Fig. I (a). The functions of the other three plasmids were not established. The small $5.8 \times 10^{6} \mathrm{~mol}$. wt plasmid was eliminated at the same time as pED502 or pED503, or lost spontaneously in a few cases. Furthermore, no positive correlation was observed when representative strains cured for either function were tested for the simultaneous elimination of the other function. These findings indicate that the production of Pep 5 and penicillin resistance by strain 5 are controlled by two distinct plasmids.

In addition to loss of Pep 5 production, $S$. epidermidis 5 Pep $5^{-}$variants were susceptible to the bactericidal action of the peptide. This could be demonstrated by using overnight cultures of $S$. epidermidis 5 wild-type, $S$. epidermidis 5 Pep $5^{-}, S$. epidermidis $5 \mathrm{Pen}^{-}$, and for control $S$. cohnii 22 as indicator strain for Pep 5 production. With $S$. epidermidis 5 Pep $5^{-}$and $S$. cohnii 22 


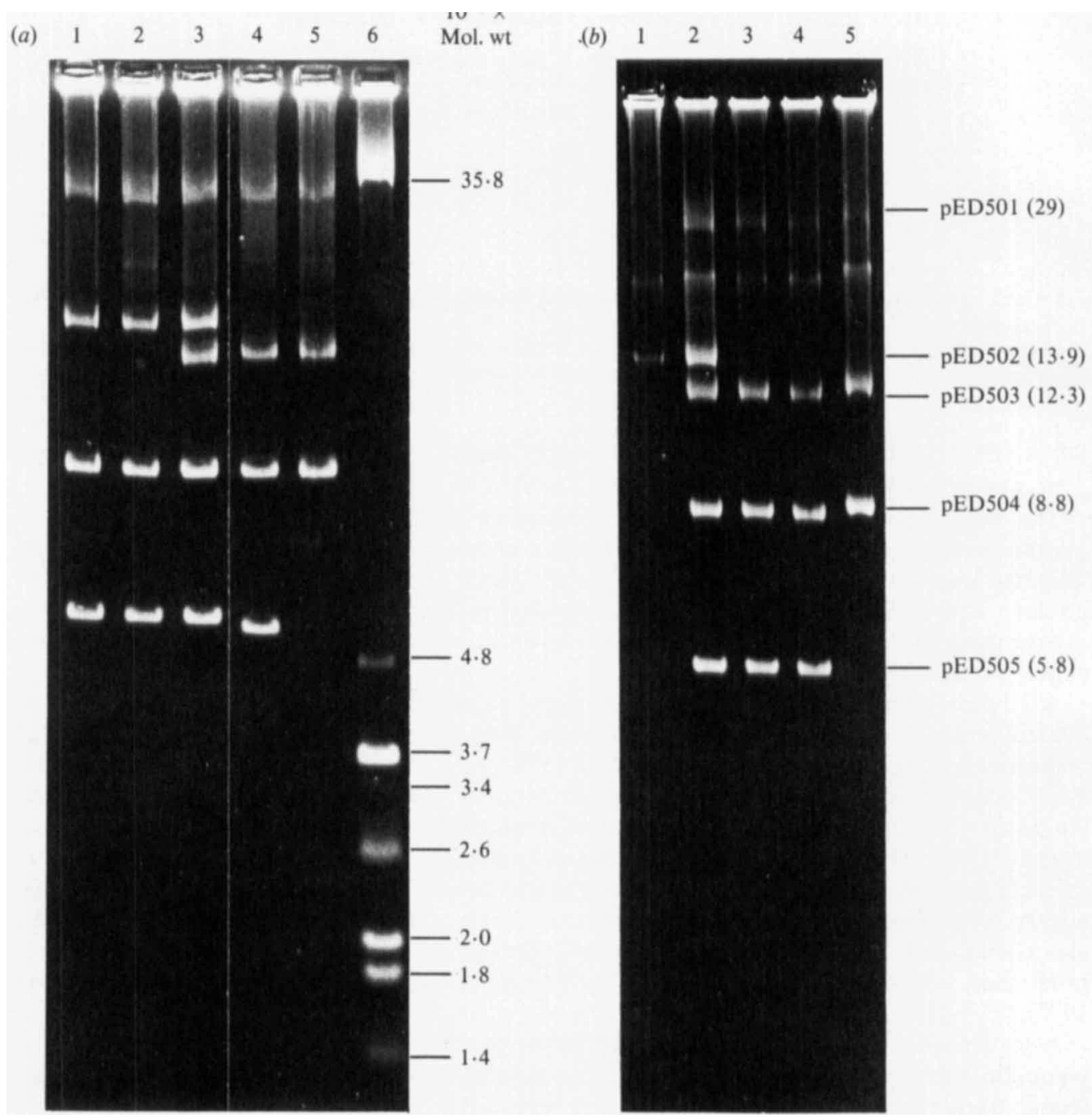

Fig. 1. Agarose gel electrophoresis of plasmid DNA obtained from Staphylococcus epidermidis 5 and its cured variants, and from Pep 5 producing and penicillin resistant transformants. (a) Staphylococcus epidermidis 5 Pep 5- (lanes 1 and 2); S. epidermidis 5 (lane 3); S. epidermidis 5 Pen- (lanes 4 and 5); Escherichia coli V517 (lane 6) as molecular weight standard (Macrina et al., 1978). (b) Staphylococcus aureus RN 981 transformed for penicillin resistance with pEDS02 (lane 1); $S$. epidermidis $S$ (lane 2); $S$. epidermidis 5 Pep 5- transformed for Pep 5 production with pEDS03 (lanes 3 to 5). Numbers in parentheses are $10^{-6} \times$ mol. wt. The DNA was prepared by the screening method as described in the text. A $25 \mu \mathrm{l}$ sample of DNA was mixed with $10 \mu \mathrm{l}$ dye solution and subjected to electrophoresis ( $50 \mathrm{~V}$, $16 \mathrm{~h})$.

as indicators, large zones of inhibition were observed, whereas in the cases of $S$. epidermidis 5 wild-type and $S$. epidermidis $5 \mathrm{Pen}^{-}$, no inhibition of growth was visible. To confirm these results, quantitative sensitivity tests with purified Pep 5 (Sahl \& Brandis, 1981) were carried out with the four above-mentioned strains. By comparison with $S$. cohnii 22, which by definition is sensitive at a concentration of 1 arbitrary unit (a.u.) Pep $5 \mathrm{ml}^{-1}$ (Sahl \& Brandis, 1981), the strain $S$. epidermidis 5 Pep $5^{-}$was inhibited by 4 a.u. The other two strains tested were not inhibited by the highest concentration obtainable in aqueous solution $\left(40000 \mathrm{a} . \mathrm{u} . \mathrm{ml}^{-1}\right)$.

Immunity of the producing strain to its own substance has also been reported for $S$. epidermidis 1580 (Jetten \& Vogels, 1973) and S. aureus 414 (Gagliano \& Hinsdill, 1970), 
whereas $S$. aureus C55 was shown to be resistant, i.e. unable to adsorb staphylococcin C55 (Dajani \& Taube, 1974). Bacteriocin cured cells of $S$. aureus strain C55 adsorb the staphylococcin and become sensitive. The mechanism of the immunity of $S$. epidermidis 5 at the molecular level is not yet clear. It can only be stated that the presence of the bacteriocin plasmid renders the cells immune to the action of Pep 5.

\section{Transformation of recipient strains to Pep 5 production and penicillin resistance}

Polyethylene-glycol-mediated protoplast transformation was used to confirm the results of curing studies and the association of Pep 5 production and penicillin resistance with specific plasmids. Strains $S$. epidermidis 5 Pep 5-, S. epidermidis 5 Pen- $^{-}, S$. aureus RN 450, and $S$. aureus RN 981 were used as recipients. Transformation of Pep 5 production occurred only in the previously cured strain $S$. epidermidis 5 Pep $5^{-}$with a transformation frequency of $3.4 \times 10^{-2}$. No Pep $5^{+}$transformant could be detected among $7 \times 10^{4}$ regenerants of $S$. aureus $R N 981$ and $S$. aureus $R N$ 450. In contrast, penicillin resistant transformants could be isolated from strain $S$. aureus RN 981, with frequencies of about $1 \times 10^{-3}$, but not from $S$. aureus strain RN 450 nor from $S$, epidermidis 5 Pen $^{-}$.

The failure of transformation of Pep 5 production into the recipient $S$. aureus RN 981 contrasted with the ability of this host to acquire and express the penicillin resistance plasmid. This could be explained as follows.

(i) Either the Pep 5 plasmid could not be transferred into $S$. aureus RN 981 or it could not express its function if present in this strain.

(ii) There are two or more genetic loci necessary for the production of active Pep 5 . In this case, plasmid pED503 could encode for an inactive precursor of Pep 5, which has to be modified enzymically for activity. The genetic information for the enzyme(s) could be located on the chromosome or one of the other plasmids (pED501 or pED504).

The latter explanation is likely, because Pep 5 contains lanthionine (unpublished results). This non-protein amino acid, a thioether derived from serine and cysteine, is also present in the peptide antibiotics nisin and subtilin. Ingram (1969) showed that lanthionine is posttranslationally formed in nisin precursor peptides, thereby creating intramolecular ring structures in those peptides. Assuming a similar synthesis of lanthionine in Pep 5, it cannot be produced in a recipient lacking the modifying enzyme.

Fifteen of the penicillin resistant and fifteen Pep 5 producing transformants were screened for their plasmid DNA content (Fig. $1 b$ ). All penicillin resistant transformants of $S$. aureus RN 981 contained the $13.9 \times 10^{6} \mathrm{~mol}$. wt plasmid, which is in the molecular weight range of previously reported penicillin resistance plasmids $\left(10 \times 10^{6}\right.$ to $\left.25 \times 10^{6}\right)$ of $S$. epidermidis (Totten et al., 1981) and $S$. aureus (Novick et al., 1979).

All Pep 5 producing transformants of $S$. epidermidis 5 Pep 5- had regained the $12.3 \times$ $10^{6} \mathrm{~mol}$. wt plasmid; six clones lost the small $5.8 \times 10^{6} \mathrm{~mol}$. wt phenotypically cryptic plasmid. Furthermore it was observed that $14 \mathrm{~S}$. epidermidis 5 Pep $5^{-}$transformants lost the $13.9 \times$ $10^{6}$ mol. wt plasmid upon protoplast formation, so that most $S$. epidermidis 5 Pep 5transformants showing Pep 5 production lacked the $13.9 \times 10^{6} \mathrm{~mol}$. wt plasmid and were sensitive to penicillin (Fig. 1 b). The fact that protoplast formation eliminates the $13.9 \times 10^{6} \mathrm{~mol}$. wt plasmid effectively in $S$. epidermidis 5 Pep 5 - may also explain the observation that this plasmid could not be transferred back into clones previously cured of penicillin resistance.

The results obtained by transformation supported the curing studies showing that Pep 5 production and immunity to this peptide are encoded on the $12.3 \times 10^{6} \mathrm{~mol}$. wt plasmid. This is similar to the situation described for certain colicins like El, K, Ia, etc. The immunity to colicin la depends on a 14000 to $14500 \mathrm{Dal}$ polypeptide (Weaver et al., 1981), which is located in the cytoplasmic membrane and encoded on the ColIa plasmid. The immunity is thought to be brought about by a stoichiometric complex of immunity protein and colicin. Thus, an immunity breakdown was observed with colicins $\mathrm{Ia}$ and $\mathrm{Ib}$ when the concentrations of the colicins that were applied were higher than the amount of immunity protein in the inner membrane (Konisky, 1982). This was not observed with $S$. epidermidis 5 , which remained immune at the highest Pep 5 concentration obtainable in aqueous solution. 
We thank Armgard Viebahn for expert help in electron microscopy. Strains were generously provided by $R$. $P$. Novick (S. aureus) and F. Schmidt (E. coli).

This work was supported by the Deutsche Forschungsgemeinschaft (Sa 292/2).

\section{REFERENCES}

BERNHARD, K., SCHREMPF, H. \& GoEbEL, W. (1978). Bacteriocin and antibiotic resistance plasmids in Bacillus cereus and Bacillus subtilis. Journal of Bacieriology 133, 897-903.

BiRnbolm, H. C. \& DolY, J. (1979). A rapid alkaline exiraction procedure for screening recombinant plasmid DNA. Nucleic Acids Research 7, 1513-1523.

Bounanchaud, D. H., Scavizzi, M. R. \& Chabaert Y. A. (1968). Elimination by ethidium bromide of antibiotic resistance in enterobacteria and staphylococci. Journal of General Microbiology 34, 417-425.

Chang, S. Cohen, S. N. (1979). High frequency transformation of Bacillus subtilis protoplasts by plasmid DNA. Molecular and General Genetics 168, 111-115.

Clewell, D. B. \& Helinsxi, D. R. (1969). Supercoiled circular DNA-protein complex in Escherichia coli: purification and induced conversion to an open circular DNA form. Proceedings of the National Academy of Sciences of the United States of America 62, 1159-1166.

DAsani, A. S. \& Taube, Z. (1974). Plasmid-mediated production of staphylococcin in bacteriophage type 71 Staphylococcus aureus. Antimicrobial Agents and Chemotherapy 5, 594-598.

Gagliano, V. J. \& Hinsdill, R. D. (1970). Characterization of a Staphylococcus aureus bacteriocin. Jourmal of Bacteriology 104, 117-125.

Götz, F., AHRNe, S. Lindberó, M. (1981). Plasmid transfer and genetic recombination by protoplast fusion in staphylococci. Journal of Bacteriology 145, 74-81.

INGRAM, L. C. (1969). Synthesis of the antibiotic nisin: formation of lanthionine and beta-methyl-lanthionine. Biochimica et biophysica acta 184, 216-219.

Jetten, A. M. \& Vogels, G. D. (1972). Nature and properties of a Staphylococcus epidermidis bacteriocin. Journal of Bacteriology 112, 243-250.

Jetten, A. M. \& VoGeLs, G. D. (1973). Characterization and extrachromosomal control of bacteriocin production in Staphylococcus aureus. Antimicrobial Agents and Chemotherapy 4, 49-57.

JeTtEN, A. M., VoGELS, G. D. \& DE WINDT, F. (1972). Production and purification of a Staphylococcus epidermidis bacteriocin. Journal of Bacteriology 112 , 235-242.

KLEINSCHMidT, A. K. (1968). Monolayer techniques in electron microscopy of nucleic acid molecules. Methods in Enzymology 12B, 361-377.

Konisky, J. (1982). Colicins and other bacteriocins with established modes of action. Annual Review of Microbiology 36, 125-144.

LAUPS, R. \& Kaulfers, P.-M. (1977). Molecular characterization of a plasmid specifying ampicillin resistance and its relationship to other $\mathbf{R}$ factors from Haemophilus influenzae. Journal of General Microbiology 103, 277-286.

LiNDBERG, M. (1981). Genetic studies in Staphylococcus aureus using protoplasts : cell fusion and trans- formation. In Staphylococci and Staphylococcal Infections, pp. 535-541. Edited by J. Jeljaszewicz. Stuttgart: Gustav Fischer Verlag.

Macrina, F. L., Kopecto, D. J., Jones, K. R., A yers, D. J. \& MCCOWEN, S. M. (1978). A multiple plasmid-containing Escherichia coli strain: convenient source of size reference plasmid molecules. Plasmid 1, 417-420.

Nakamura, T., Yamazaki, N., TaNiguchi, H. \& Fummura, S. (1983). Production, purification, and properties of a bacteriocin from Staphylococcus aureus isolated from saliva. Infection and Immunity 39, $609-614$.

Novick, R. P. (1967). Properties of a cryptic highfrequency transducing phage in Staphylococcus aureus. Virology 33, 155-166.

Novicx, R. P. \& BouANCruUd, D. (1971). Extrachromosomal nature of drug resistance in Staphylococcus aureus. Annals of the New York Academy of Sciences 182, 279-294.

Novick, R. P., MURPhy, E., Gryczan, T. J., Baron, E. \& Edelyan, I. (1979). Penicillinase plasmids of Staphylococcus aureus: restriction-deletion maps. Plasmid 2, 109-129.

Rocolsky, M., Warren, R., WILEY, B. B., NAKaMURA, H. T. \& Glascow, L. A. (1974). Nature of the genetic determinant controlling exfoliative toxin production in Staphylococcus aureus. Journal of Bacteriology 117, 157-165.

Rostas, K., Dobritsa, S. V., Dobritsa, A. P., Koncz, C. S. \& ALFöLDI, L. (1980). Megacinogenic plasmid from Bacillus megaterium 216. Molecular and General Genetics 180, 323-329.

SAHL, H.-G. Brandis, H. (1981). Production, purification and chemical properties of an antistaphylococcal agent produced by Staphylococcus epidermidis. Journal of General Microbiology 127, 377-384.

SAHL, H.-G. BRandis, H. (1982). Mode of action of the staphylococcin-like peptide Pep 5 and culture conditions effecting its activity. Zentralblart für Bakteriologie Mikrobiologie und Hygiene, I. Abteilung Originale A252, 166-175.

SAHL, H.-G. \& BRANDIS, H. (1983). Efnux of low-M, substances from the cytoplasm of sensitive cells caused by the staphylococcin-like agent Pep 5 . FEMS Microbiology Letters 16, 75-79.

Sonstein, S. A. \& BALDWIN, J. N. (1972). Loss of the penicillinase plasmid after treatment of Staphylococcus aureus with sodium dodecyl sulfate. Journal of Bacteriology 109, 262-265.

TAGg, J. R., DANAN, A. S. \& Wannamaker, L. W. (1976). Bacteriocins in Gram-positive bacteria. Bacteriological Reviews 40, 722-756.

Totren, P. A., Vidal, L. BALdWIN, J. N. (1981). Penicillin and tetracycline resistance plasmids in Staphylococcus epidermidis. Antimicrobial Agents and Chemotherapy 20, 359-365.

WARREN, R., ROGOLSKY, M., WILEY, B. B. \& 
Glascow, L. A. (1974). Effect of ethidium bromide on elimination of exfoliative toxin and bacteriocin production in Staphylococcus aureus. Journal of Bacteriology 118, 980-985.

Weaver, C. A. Redrorg, A. H. \& Konisky, J. (1981).

Plasmid-determined immunity of Escherichia coli K-12 to colicin la is mediated by a plasmid-encoded membrane protein. Journal of Bacteriology' 148, 817828.

Wyman, L., Goering, R. V. \& Novick, R. P. (1974). Genetic control of chromosomal and plasmid recombination in Staphylococcus aureus. Genetics 76, 681702. 